\title{
PRIMARY SCHOOL STUDENTS' PERCEPTION OF ART AND SCIENCE INTEGRATION IN CLASSROOM
}

\author{
Dwi Wulandari \\ Fakultas Bahasa dan Seni, Universitas Negeri Yogyakarta \\ Email: dwiwulandari@uny.ac.id
}

\begin{abstract}
This research reveals understanding of students' perceptions toward the interrelationship of art and science is needed so that integrated learning is carried out in accordance with the needs and natural conditions of pupils. Using small scale ethnographic action research in which I took on the principal role as teacher-researcher, the present research aims to understand how primary school students experience and perceive the relationship between art and science within classroom context. The study explored the perception of thirteen Year-5 pupils in one state school in West Papua, Indonesia. Data were gathered using observation and interview methods using field notes, videos, audio recordings, and transcriptions and the analysed using a thematic analysis approach. It is found that there has been a shift of their perceptions from initially dichotomising art and science as two different areas, to seeing similarities and connections between the two disciplines. The pupils' perceptions are seemingly influenced by the nature of the study which aims to link the art and science, student's previous experiences, timetable management, teachers, classroom and school settings and conditions.
\end{abstract}

Keywords: Students' perception; art-science integration, STEAM Education

\section{PERSEPSI SISWA SEKOLAH DASAR TERHADAP INTEGRASI SENI RUPA DAN IPA DALAM PEMBELAJARAN DI KELAS}

\begin{abstract}
Abstrak
Penelitian ini merupakan usaha untuk mengetahui bagaimana siswa sekolah dasar mengalami dan memahami hubungan antara seni dan IPA dalam konteks pembelajaran di kelas. Penelitian ini merupakan penelitian tindakan yang bersifat etnografis berskala kecil dengan menempatkan peneliti sebagai guru-peneliti. Penelitian ini mengeksplorasi persepsi tiga belas siswa kelas 5 di satu Sekolah Dasar Negeri di Papua Barat, Indonesia. Data dikumpulkan dengan menggunakan metode observasi dan wawancara dengan instrumen berupa catatan lapangan, video, rekaman audio, dan transkripsi. Data kemudian dianalisis menggunakan pendekatan analisis tematik. Ditemukan adanya perubahan persepsi peserta didik yang awalnya mendikotomi antara seni dan sains yang kemudian beralih menjadi menganggap bahwa kedua disiplin ilmu tersebut memiliki kesamaan dan keterhubungan. Persepsi siswa nampaknya dipengaruhi oleh kondisi penelitian yang menciptakan suasana pembelajaran tematik terintegrasi, pengalaman siswa sebelumnya, manajemen jadwal pembelajaran, serta kondisi dan pengaturan kelas, guru dan sekolah.
\end{abstract}

Kata Kunci: persepsi siswa, integrasi seni-sains, STEAM Education 


\section{INTRODUCTION}

The discourse for more comprehensive and integrated education is increasing in this 21 st century. This is based on an understanding that the division between different disciplines seems to be largely irrelevant and 'go against human nature' (Daugherty, 2013) especially at a young age. It is believed that children's perceptions of the world can be very different from those of adults, the latter tending to be fragmented as it is largely based on background knowledge. Children tend to make sense of the world in a unique, holistic way. Regarding this, Barnes (2015) asserts that education should not curb the development of children with adultdominating curricula and standards; it has a duty to make space for children to enjoy the learning process in accordance with the nature of children themselves and their unique world vision. Therefore, education needs to study more deeply about this integrated education discourse in all possible fields.

Some disciplines being studied about their linkages and advantages if presented in integrative education are art and science which are also mentioned as visual art and natural science respectively. The discourse of art and science integration is not groundless. These two disciplines have been long studied that have commonalities and complementary to each other (Robson et al, 2005). Grounded by the nature of art and science's intertwining, some experts have considered the possibility of connecting these two disciplines in primary curriculum to achieve higher quality learning. However, it is necessary to harmonize between the opinions of experts with the students' perceptions themselves so that an integrative approach in art and science education will be designed appropriates to the nature of the learning subjects themselves who will experience it.

The promising prospect in recent years to integrate art and science in educational context has been initiated through STEAM (Science, Technology, Engineering, Arts, and Mathematics), a learning approach initially emerged in the USA, where arts is considered as an innovation and creativity-related components in STEM to foster a competitive and innovative workforce which is equally as critical and vital as the four STEM aspects (Daugherty, 2013; The Congressional STEAM Caucus, 2013). Similar projects have also been initiated within Europe. One of them is CREATIONs project (Chappell et al, n. d). Intended for teachers and students aged 8 to 20 , this project essentially aims to examine the role of arts and creativity to increase student engagement in learning especially in science education, analysing how theories about artistic pedagogy and creativity (especially developed by the University of Exeter) are implemented and how they affect students. The project also explores the role of collaboration between researchers, teachers, scientists and artists to create high quality learning. These discourses and projects has encouraged more intense implementation of arts and science integration in classroom context.

Any suggestion to integrate science and art may lead to questions about the justification in choosing these two seemingly unrelated disciplines. Adding the arts to STEM (Science, Technology, Engineering, and Mathematic) education to create STEAM, for example, often results in this being challenged, with the reasoning that, if the arts are added to STEM, all the other subjects might need to be added as well (Daugherty, 2013). In response to this, it is necessary to identify and consider the nature of the linkage between art and science.

The formal combination of art and science has always prompted lengthy discussion. Colombo (1994) believes that art and science, including technology have been 'intertwined' for a very long time indeed. In the seventeenth century it was believed that these disciplines had begun to separate because the occurrence of 'two cultures', a gulf of mutual incomprehension separating them, triggered the process of dissociation between humanistic culture and the culture of science and technology (Colombo, 1994; Daugherty, 2013; Snow, 1960). However, the commonalities between them have still emerged and can be 
identified throughout history. Reflecting on the lives of some historical artist-scientists such as Leonardo da Vinci, Kouzminov (1994: 116) argues that 'art and science are essential parts of human life in the contemporary world and are possibly the major forces of our progressive development. They are complementary to each other'. This demonstrates how art and science cannot be truly separated in life. They are not the same, but they are connected to each other in supporting the basic areas of human activity and productivity.

Robson et al (2005) emphasise that these two disciplines are not randomly selected. Some academics from wide-ranging backgrounds, including Dewey (1980), Colombo (1994), Kouzminov (1994), Bohm (1998), Wenham (1998), Kemp (2000), Deckert (2001), Caranfa (2001) and Eisner (2002), have identified commonalities between art and science and the benefits that may be achieved through their integration in education. Accordingly, Robson et al (2005) have identified five main categories of art and science commonalities, namely: a) 'modes of inquiry'; b) 'fields of study'; c) 'experimentation', d) 'creativity and imagination' and e) 'aesthetic experience and artistic attitude'.

The first area 'modes of inquiry', includes: selecting and gathering information; observing and recording; exploring; investigating and analysing. In contemporary art education, these skills are essential to develop what is known as 'informed art-making' in which art working is supported by exploration and discovery of object qualities, exactly the same as science investigation.

In the second area 'fields of study', both art and science have considerable breadth of knowledge and infinite development where they can naturally influence one another. Art often helps or stimulates further scientific investigations, and equally science can enrich artistic development.

The third commonality, 'experimentation' or testing is the process which may include repeated work to find necessary data or results. In science experimentation can provide useful resources for a hypothesis and in art, as Dewey (1980) states, each new artwork needs to be experimented upon through means and materials.

The fourth category of shared commonality is 'creativity and imagination'. In both disciplines, learners or practitioners usually experiment in imaginary situations, and as such creativity has become an essential part of producing new ideas or products which are both commonly driven by the learners' imagination.

And the last, 'aesthetic experience and artistic attitude' is not the privilege of arts only, but also the nature of science processes and products. To some extent, activity in science reflects that the actors also show the sense of aesthetic and artistic.

The identification of these five shared commonalities of art and science allows education practitioners to better justify the suggestion of art and science synchronisation in school curricula. However, empirical data which proves whether the opinions of the theorists are in line with the conditions and perceptions of children as subjects of education are still limited. Therefore, this research primarily seeks to understand how primary school students (particularly Year 5) experience and perceive the relationship between art and science in classroom context. Using an interdisciplinary cross-curricular approach, the analysis will be linked to the current Indonesian curriculum.

\section{METHOD}

The overreaching aims of the research presentedaretounderstandstudents'perceptions of the connection between art and science, therefore, I made a decision to use a small scale ethnographic action research method under the qualitative-interpretive paradigm in which I took a role as teacher-researcher (Pine, 2009; Pole \& Morrison, 2003). This study is based on my exploration of practice-based issues using data gathered from my own classroom. The project took place at one of Indonesian state primary school located in West Papua Province and involved Year 5 students (10-11 years old) 
in one class of 32 children for three weeks from mid-May to early June 2017. The learning project was connected with Kurikulum 2013 (K13), an Indonesian current curriculum in which implementating integrated and thematic learning for primary level (Kemendikbud, 2014), and specifically that of Year 5 for Art and Science subjects. However, in the chosen classroom where I conducted the research, the timetable still separated the subjects or the school had not implemented the thematic curricula instructed by the K13. The selected theme was Human and Animal's Body theme (Kemendikbud, 2014). Therefore, the main activity of the project in science class was making movable creation based on a scientific inquiry about musculoskeletal system. Meanwhile in art class, the project is making a movable puppet representing local arts and culture.

In order to generate trustworthy and reliable outcomes, the research was collaborative. As such, the researcher works closely together with students and teachers as 'critical friends' whose essential opinions and 'voices' are all equally significant for the research (Baumfield et al, 2008; Pine, 2009). From the interviews, I collected data from four selected students by using the purposive sampling method and nine other students who had joined the whole activities of the project. Four selected students were interviewed individually before and after the project to make clear comparisons between their perceptions before and after the projects. Another nine students were interviewed in three small groups after joining the project to shape and give more depth understanding of the previous findings. All the interviews were using a semi-structured interview. Meanwhile through observation, I and my critical friends, Rani and Lina, the participating school arts teacher and class teacher (with academic background in Indonesian but have a few experiences in teaching mathematics and science) respectively, observing verbal and non-verbal activities and responses of the students during the project. This observation is documented in field notes, photos and videos.
The research methods employed here have generated several forms of data consisting of field notes of mine and critical friends, photographs and videos of some important moments of learning, audio recordings and transcriptions of the interviews. These types of data were analysed simultaneously and continuously since the research sought to seek the patterns or the consistencies in the ways its subjects think, say, and behave (Fraenkel et al, 2012). The data were coded and then arranged using a thematic analysis approach which examined the data according to the commonalities, relationships and differences.

The research has taken into consideration all ethical procedures, particularly those of British Educational Research Association (BERA, 2011), which include: guaranteeing voluntary and informed participation; ensuring a safe and appropriate research design, and ensuring anonymity by the use of pseudonyms. Full ethical approval was obtained from the schools, from parents and from the pupils involved before any of the work was undertaken.

\section{RESULTS AND DISCUSSION}

To understand students' perceptions more fully and as to what extent their perceptions changed after joining the project, data was analysed from pre- and post- interviews of selected pupils. The selected pupils were as follows: Ani (a high achiever in science lessons - female); Budi (a low achiever in science lessons - male); Iwan (a high achiever in art lessons - male), and Toni (a low achiever in art lessons - male). However, to support the analysis, the data were also enriched by other sources i.e. nine other pupils (female: Aga, Yela, Sela, Tia, Syifa, Gedi and male: Reno, Dito, Arya) who joined the whole project and my critical friends, Rani and Lina. The results are described as follows:

\section{Pupils' perceptions before the project}

From the pre-interview findings, only Budi appears to be conscious of the connection between art and science by attributing his statement to his experience of attending a workshop out of town. He says: 
"There is [relationship] like [the topic about] the light, making binoculars with glass. It is a kind of art... [Learning about] the light is science. The glass and making the binoculars are art."

However, he appears to feel that this connection is limited to certain areas, with there not necessarily being the possibility of combining all themes of the two disciplines. When answering questions about the possible integration of art and science lessons at school, he replies:

"They can [be integrated], but only a few. In making creations about the light, it is science as well. But not in drawing and singing. Because science learns about natural resources and doing experiments, but in singing we learn about the song."

Budi opines that some of the arts learning aspects such as drawing and singing have nothing to do with science because they are related only to the achievements of art learning.

Meanwhile, the other three pupils do not seem to see the interrelation between art and science. They describe art and science as having different qualities. Toni explains:

"All this time, when I made science experiments, there was not any art I found... [For example] when we used mercury and sugar, if I am not mistaken, like [making] asphalt, I think that was not art. Art is like the paintings usually displayed in the museum... Art and science are different, because art is... someone making something beautiful, but science is someone experimenting."

Toni seems to think that art is related to aesthetics whereas science is not, and that the experimentation process only exists in science. $\mathrm{He}$ expresses his belief in art that there are only making-artwork activities, and that these activities are different from experimentation. Iwan has the same perception about these characteristics, adding that he believes that science is related to things that have technical functions or benefits. He states:
"In science, [for example] we used magnets to pull nails out of the ground."

Equally Iwan and Toni refer to the meaning of art's function or benefit as being more commonly associated with: economic properties (can be sold); used as a gift and or perhaps for participation in open art exhibition.

In addition, Ani says that science's essential nature is as 'giving knowledge', such as adding insights about animals and plants so she knows how to take care of them. Moreover, Toni defines this nature as 'enhancing cleverness'. Ani and Toni appears to assume that 'intelligence' only applies to the cognitive ability related to science knowledge content.

\section{Pupils' perceptions after the project}

In the post-interview, overall the four pupils appear to be of the same view that art and science are linked. The three pupils who had previously claimed there to be no connection between art and science had changed their perspectives. Toni asserts that:

"[Art and science are] related. The relationship is there when making the puppet. You (teacher-researcher) asked us to make it can move like an animal or a human. So we connected science with artwork. "

Similarly, Ani claims:

"Related. For example, science is in the system of human motion, such as our hands. Group four made it (a hand), right? They made a hand and it could move. Its movement is science and making it (the process) is art."

In post-interview, other pupils who attended the whole project offered the same opinion as these four pupils. Aga says:

"For art performances yesterday we made a creation, science also has a creation. [For example] hands can be moved by a combination of science and art. "

While Tia states:

"We learned the skull, designed it, so it is like composing parts of the body. We know that muscle function is like this and such, 
the way it moves ... then it is combined with art so the creation can move. "

Regarding the perceptions of Year 5 students, it can be seen that there has been a shift of their perceptions from initially dichotomising art and science as two different areas, to seeing similarities and connections between the two disciplines. Previously, most students perceive that art has distinctive qualities from science, such as aesthetics, making-artwork activity, economic properties (can be sold), used as a gift and or perhaps for participation in open art exhibition. Meanwhile some qualities that only emerge in science are experimentation, technical functions or benefits and enhancing cognitive ability. To some extent, pupils expressed their perception that the moment of truth is only owned by sciences. In fact, arts also have a balance mixture between moment of beauty and moment of truth (Kasiyan, 2017). However, students' perceptions eventually seem to be in line with the literature since all of them change their opinion and judgment after joining the project. They feel that art and science has similar and related qualities such as technical and technological functions and benefits, data/ information inquiries, making process which includes experimentation and creativity, and the creations or products. Although aesthetics and artistic aspects are not directly mentioned by them, it can be observed that the students unconsciously always attempted to do and make such aesthetic and artistic actions and products during both art and science class projects. It could be observed that the pupils experienced the sense of aesthetic enjoyment in making process which includes taste, fantasy, and awareness (Iryanti, 2016).

It could be reasonably concluded that there has been a shift in pupils' perceptions after the project from initially separating the two dimensions of art and science into agreeing that there could be a link between them. The pupils' perceptions are seemingly influenced by the nature of my study which aims to link the art and science, student's previous experiences, timetable management, teachers, classroom and school settings and conditions.
Firstly, as stated by Kolb and Kolb (2012) and Turkka et al. (2017), the pupils' perceptions could be influenced by several causes including the factor of teacher instruction and their previous experiences. The first seemed to be one of possible factors since the nature of my research and my teaching was making the links visible to them. Meanwhile regarding the previous experience factor, it can be seen from Budi, for example, who since the preinterview, now appears to be more aware of the connection between art and science, due to his experience of joining the workshop outside the school curriculum. Unfortunately, according to Budi, the experience was not derived from activities at school. Supported this statement, Ani and Toni both insist that they never try to connect art and science at school. As such it is immediately apparent that these pupil interviewees had changed their perception of the dichotomy between these two disciplines, because of their participation in this research project.

One analysis that can be drawn from preproject observations conducted previously is that science teacher rarely mentioned of any cross-curricular links, so that affected students' perceptions. Lessons which were didactivetraditional made the activities in the classroom more teacher-centered. The learning activities could appear monotonous i.e. the teacher explains, the pupils take notes, and after the material targets are completed, the students are given practice tests for the exam. In addition, practical activity and scientific experiments were only offered relatively infrequently to the pupils, so pupils are often left with the impression that science lessons are only related to the acquisition of cognitive knowledge.

Another basic factor affecting pupils' perceptions may be the seemingly low level of teacher professionalism. For example, during the last few weeks of term, when this research took place, the science teacher of Year 5 quite often did not attend the class with the justification of having already completed the set curriculum learning targets. This specific case is one of the reasons I was unable to work 
in partnership with him. During that time, the pupils were just asked to re-learn the materials and tests independently without supervision. The pupils seemed to dislike and be dissatisfied with their science learning. Unfortunately, the science teacher continued to be retained because the school was short of teachers. These conditions seemed to result in science teaching and learning being of a low standard. It was possible to observe that the concept of science itself was less understandable for the pupils. For example, in informal conversations with me during pre-project observation, pupils were difficult to explain the previous science topic and how they made sense of it. So it is therefore difficult for them to link science with other disciplines.

In contrast, the previous art lessons were delivered with considerable various approach and were full of practical activities, hence it seemed that the pupils liked art lessons. The teachers had also tried to integrate their lessons with the science lessons. However, the two things which could be observed were, firstly, that these integrations were more like 'service connections' (Russell-Bowie, 2009). This is where the achievement of science learning in art is not a goal within itself, but rather the science is only serving to facilitate the increased attainment of art targets. Secondly, the art education here tended to focus more on locally-based art, which made the space for general creativity more limited. In creating pieces of art, the type of artwork had already been pre-determined by the teacher so that pupils were more likely to copy rather than make creations of their own.

One further analysis lead to the conclusion that, perhaps due to the rigid schedule of the school's timetable, pupils' perceptions of subjects were already fragmented. The feeling was expressed that as there is a special allocation of time for each lesson, it could be considered strange for pupils to learn another subject's content in another lesson in a different subject. Sela questions this during the preproject observation:

\section{"Why do we in science learn about religion} and mathematics instead?"

This shows that, although the centre curriculum supports thematic and integrated learning as well as the achievement of four core competencies focusing on different aspects (spirituality, attitude, knowledge, and skills) (Kemendikbud, 2016; Kemendikbud, 2013), the school still seems limited in its realisation of 'holistic learning' (Gardener, 1983), which allows 'children to move across the disciplines as they learn[ed] about aspects of their world' (McNaughton, 2010: 292). Rina and Lina indicate that their and other teachers' performances are limited due to the lack of support from the school and attribute this to issues of inequality and lack of inclusion. They acknowledge too the limitations of funding, facilities, resources and teacher continuous professional development (CPD) which have made the standard of the schools in their area somewhat lower than in other regions of Indonesia.

\section{CONCLUSION}

The research has shown that there is a shift of primary school students' perceptions of art and science integration in classroom learning activities. Initially, most of them dichotomised art and science as two different areas. Meanwhile after joining the project, all of the students agreed that they see similarities and connections between the two disciplines. These similarities and connections includes some aspects such as technical and technological functions and benefits, data/ information inquiries, making process which includes experimentation and creativity, and the creations or products. However, one of significant aspects namely aesthetics and artistic activities was not directly mentioned by the students. This may need more analysis in the future about how children perceive aesthetics and artistic aspects within art and science integrated learning.

It can also be noticed from the results that students' perception toward the connection of art and science disciplines is highly depended 
on how adults manage and present these subjects in school and classroom. While school stakeholders or teachers present the subject with rigid separation of content and schedule, the students will perceive each subject as discipline which stand alone, cannot link various information from various disciplines to gain a more comprehensive understanding, and hinder the emergence of creative problem solving by utilizing the relations between the subjects. This do 'go against human nature' (Daugherty, 2013: 11) that see the world in more holistic ways. Therefore, the implementation of integrative learning in classroom need more depth attention to reach the expected results.

The issue of the research presented in this paper, however, still need to be explored more deeply especially within larger context and other levels of education. It can be noticed that the results are highly linked with school context, so that other similar research within other contexts will give more comprehensive understanding about the issue. Moreover, the analysis of the connection of art and science in natural learning context or learning with no or not too much intervention of adults may also be needed. This kind of investigation may lead to the understanding how children actually learn about a particular field in their natural situations.

\section{ACKNOWLEDGEMENT}

This research is fully supported and sponsored by LPDP, Indonesian Ministry of Finance, and supervised by Dr. Emese Hall, University of Exeter.

\section{REFERENCES}

Barnes, J. 2015. Cross-curricular Learning 3-14. London: SAGE Publications Ltd.

Baumfield, V., Hall, E., \& Wall, K. 2008. Action

Research in the Classroom. London: SAGE Publications Ltd.

BERA.2011.EthicalGuidancesfor Educational

Research. Retrieved from: https://www. bera.ac.uk/wp-content/uploads/2014/02/ BERA-Ethical-Guidelines-2011. pdf?noredirect $=1 \quad$ [Accessed: February 20th, 2017]

Bohm, D. 1998. in Nichol, L (ed) (1998) On Creativity. London. Routledge.

Caranfa, A. 2001. Art and Science: The Aesthetic Education of the Emotions and Reason. Journal of Art and Design Education, 20(2), 151- 160.

Chappell, K., Charlotte, S., Alison, B., \& Margo, G., with Craft, A. (n. d) CREATIT: A New Pedagogical Framework For Partnering The Arts And Science In Science Education. Artikel tidak dipublikasikan. University of Exeter.

Colombo, U. 1994. Science and art, World Futures, 40:1-3, 1-5.

Daugherty, M. K. 2013. The Prospect of an "A" in STEM Education, Journal of STEM Education, 14(2), 10-15.

Deckert, D. 2001. Science and Art: Lessons from Leonardo da Vinci in Burnaford, G. Aprill, A \& Weiss, C. (eds). 2001. Renaissance in the Classroom, Arts Integration and Meaningful Learning. London. Lawrence Erlbaum Associates

Dewey, J. 1980. Art as Experience. London: Penguin.

Eisner, E. W. 2002. The Arts and The Creation of The Mind. New Haven: Yale University Press.

Fraenkel, J. R., Wallen, N. E., \& Hyun, H. H. 2012. How to design and evaluate research in education. New York: McGraw-Hill.

Gardener, H. 1983. Frames of mind: the theory of multiple intelligences. New York: Basic Books.

Iryanti, V. E. 2016. Aesthetic Enjoyment in Arts A Philosophical Study, Imaji Jornal, 14(2), 1-12.

Kasiyan. 2017. When Artists Ask Questions About Society: The Dialectical Tension Between Moment Of Beauty and Truth, Imaji Journal, 15(1), 37-47.

Kemendibud. 2013. Kurikulum 2013: Kompetensi Dasar Sekolah Dasar (SD)/ Madrasah Ibtidaiyah (MI). Jakarta: Kementrian Pendidikan dan Kebudayaan. 
Kemendikbud.2014.Organ Tubuh Manusiadan Hewan : buku guru. Jakarta: Kementrian Pendidikan dan Kebudayaan.

Kemendikbud. 2016. Permendikbud No. 24 Tahun 2016 tentang Kompetensi Inti dan Kompetensi Dasar. Jakarta: Kementrian Pendidikan dan Kebudayaan.

Kemp, M. 2000. Visualizations, The Nature Book of Art and Science. Oxford: Oxford University Press.

Kolb, A. Y., \& Kolb, D. A. 2012. Experiential learning theory. In N. M. Seel (Ed.), Encyclopedia of the sciences of learning (pp. 1215-1219). New York: Springer US.

Kouzminov, V. 1994. Remarks on art and science, World Futures, 40(1-3), 115-117

McNaughton, M. J. 2010. Educational drama in education for sustainable development: ecopedagogy in action, Pedagogy, Culture \& Society, 18:3, 289-308.

Pine, G. J. 2009. Teacher Action Research: Building knowledge democracies. London: SAGE Publications Ltd.

Pole, C., \& Morrison, M. 2003. Ethnography for Education. Berkshire: Open University Press.
Robson, D., Hickey, I., \& Flanagan, M. 2005. Flights of Imagination: Synchronised Integration of Art and Science in the Primary School Curriculum, Paper presented at the British Educational Research Association Annual Conference, University of Glamorgan, 14-17 September 2005.

Russell-Bowie, D. 2009. Syntegration or Disintegration? Models of Integrating the Arts Across the Primary Curriculum, International Journal of Education \& the Arts, 10(28), 1-23.

Snow, C.P. 1960. The two cultures and the scientific revolution. New York, NY: Cambridge University Press.

Turkka, J., Haatainen, O. \& Aksela, M. 2017. Integrating art into science education: a survey of science teachers' practices, International Journal of Science Education, 39:10, 1403-1419.

Wenham, M. 1998. Art and Science in Education: The Common Ground. Journal of Art and Design Education, 17(1). 